\title{
Energiatehokas tuotantorakennus, ERKKA
}

\author{
Teija Rantala $^{1)}$, Risto Kauppinen ${ }^{1)}$, Eero Antikainen ${ }^{2)}$, Jarkko Partanen ${ }^{1)}$ \\ 1) Savonia-ammattikorkeakoulu, PL 72, 74101 Iisalmi, etunimi.sukunimi@ savonia.fi \\ 2)Savonia-ammattikorkeakoulu, PL 6, 70201 Kuopio, etunimi.sukunimi@savonia.fi
}

\section{Tiivistelmä}

Nykyaikainen lypsykarjatalous kuluttaa runsaasti energiaa, mutta tuotantorakennusten osalta säästöä on haettu tähän saakka pääasiassa rakennuskustannuksista. Kuitenkin energiakustannukset ovat nousseet viime vuosien aikana ja niiden oletetaan nousevan tulevaisuudessa edelleen, joten energiatalouteen on syytä kiinnittää huomiota jatkossa entistä enemmän myös tuotannon kannattavuuden näkökulmasta.

Energiankulutuksessa on suuria vaihteluja tilojen välillä, vaikka tuotantosuunta ja kokoluokka olisivat samat (Työtehoseura, 2005). Suurten tilojen osuus on koko ajan nousussa ja odotettavissa on, että vuoteen 2016 mennessä puolet maidosta tuotetaan Suomessa yli 50 lehmän tiloilla, kun nykysin osuus on 20\% (Suomen Gallup Elintarviketieto Oy, 2008). Tällöin myös energiankulutuksen ja energiahuollon merkitys korostuvat entisestään. Toisaalta energiatehokkuus ja uusiutuvan energian käyttö palvelevat myös kansallisia ja kansainvälisiä ilmasto- ja ympäristötavoitteita.

ERKKA-hankkeen keskeisimpänä tavoitteena on parantaa lypsykarjatilojen taloudellista kannattavuutta vähentämällä energiankäytöstä ja -tuotannosta aiheutuvia kustannuksia. Kohderyhmänä ovat pääasiassa keskimääräistä suuremmat lypsykarjatilat ja niiden energiansäästö uudisrakentamisen osalta, mutta myös jo olemassa olevissa tuotantorakennuksissa. Keskeisenä osana hanketta on tuotetun ja kootun tiedon välittäminen tiloille ja tilojen kanssa toimiville neuvojille ym. tahoille. Hankkeessa tehdään myös mittauksia tuotantorakennusten laitteistojen energiankulutuksesta, lämpövuodoista sekä ilmanlaadusta.

Hankkeen tuloksena saadaan tietoa siitä, kuinka lypsykarjatilat voivat vähentää uusiutumattoman energian kulutusta rakennusteknisillä keinoilla, laiteteknisillä valinnoilla ja uusiutuvien energianlähteiden käytöllä ja milloin tilat voivat parantaa kannattavuuttaan näillä keinoilla. Tutkimuksen perusteella laaditaan laskentamalleja, joita voidaan hyödyntää investoivilla tiloilla, neuvonnassa sekä rakennussuunnittelussa määritettäessä eri energiantuotantomuotojen kannattavuutta. Laskennassa huomioidaan tuotannossa syntyvä energia, energiantuotantoon tarvittavat investoinnit sekä vaihtoehtoisten energiantuotantomuotojen hintakehitys.

Laskentamallien lisäksi hankkeen tuloksena syntyy suosituksia käytännöistä lypsykarjatilojen tuotantorakennusten lämmön- ja sähkönkulutuksen vähentämiseksi sekä ratkaisuiksi, jotka vähentävät tuotantorakennusten lämpöhäviöitä, ilmanvaihtoon kuluvaa energiaa tai edistävät rakennusten energiatehokkuutta. Hankkeella pyritään tuottamaan myös tietoa Maatilojen energiaohjelman kehittämiseen.

Mukana hankkessa on Savonia-ammattikorkeakoulun lisäksi ProAgria, Itä-Suomen yliopisto sekä Pohjois-Karjalan ammattikorkeakoulu. Savonialla hanke toteutetaan monialaisena tutkimuksena, jossa hyödynnetään ympäristötekniikan-, luonnonvara-alan-, energiatekniikan- sekä sähkö- ja rakennustekniikan osaamista. Hankkeen rahoittajana toimii Pohjois-Savon ELY-keskus ja se toteutetaan ajalla 1.9.2011-31.12.2013.

Asiasanat: Energiatehokkuus, energiansäästö, kannattavuus, lypsykarjatilat, uusiutuva energia 


\section{Johdanto}

ERKKA-hankkeen keskeisimpänä tavoitteena on parantaa lypsykarjatilojen taloudellista kannattavuutta vähentämällä energiankäytöstä ja -tuotannosta aiheutuvia kustannuksia. Hankkeen lähtökohtana on näkemys, että lypsykarjatilojen kannattavuutta voidaan parantaa kehittämällä niiden energiatehokkuutta ja lisäämällä uusiutuvan energian tuotantoa. Energiatehokkuuden ja uusiutuvan energian tuotannon sekä kannattavuuden yhteyden odotetaan korostuvan edelleen tulevaisuudessa. Vaikuttavina tekijöinä ovat energianhintojen nousuennuste, maatalouden tämänhetkinen riippuvaisuus varsinkin fossiilisilla polttoaineilla tuotetusta energiasta sekä ympäristö- ja energiasäädösten velvoitteet.

Suora säädösvelvoite maatalouden energiatehokkuuden lisäämiseen tulee energiapalveludirektiivistä (2006/32/EY), jonka mukaan maatalouden tulisi päästä $13 \%$ energiansäästöön vuoteen 2016 mennessä. Uusiutuvaan energian liittyen maatalouteen ei ole omaa velvoitetta, mutta sitä koskee osaltaan uusiutuvan energian direktiivin (RES-direktiivi) kansalliset uusiutuvan energian lisäysvelvoitteet. RES-direktiivin mukaan uusiutuvan energian osuus on nostettava Suomessa 38 \%:iin vuoteen 2020 mennessä. Tämä tarkoittaa 9,5 prosenttiyksikön lisäystä vuoden 2005 tasoon verrattuna, edellyttäen monipuolista uusiutuvien energiamuotojen käyttöä sekä energiatehokkuuden lisäämistä tuotannossa.

ERKKA-hankkeessa haetaan vastausta siihen, kuinka paljon energiatehokkuuden parantaminen vaikuttaa lypsykarjatilan talouteen ja kannattavuuteen. Tämän vastauksen taustaksi kootaan tietoa siitä, millaisia teknisiä ratkaisuja on olemassa energiatehokkuuden parantamiseen ja uusiutuvan energian tuotantoon sekä millaisia ovat eri ratkaisujen investointi- ja käyttökustannukset, huomioiden myös tarvittavan työmäärän. Lisäksi hankkeessa toteutetaan lämpövuoto- ja sähkönkulutusmittauksia lisätiedon kartuttamiseksi.

Hankkeen kohderyhmänä ovat keskimääräistä suuremmat lypsykarjatilat, maatalousneuvojat sekä rakennussuunnittelijat. Tavoitteena on koota ja tuottaa tietoa energiatehokkuuden ja uusiutuvan energian tuotannon teknisistä mahdollisuuksista ja kannattavuudesta tämän kohderyhmän toiminnan tueksi. Käytännön sovellutuksena laaditaan hankkeessa koottavaan ja tuotettavaan tietoon perustuvia laskentamalleja, joita kohderyhmä voi hyödyntää työssään. Kohderyhmälle viestitetään myös maatalouden energiaohjelmasta, jonka tavoitteena on vastata kansainvälisiin ilmasto- ja energiavelvoitteisiin ja niiden pohjalta asetettuihin kansallisiin tavoitteisiin.

\section{Aineisto ja menetelmät}

Hankkeen tutkimusosio on jaettu kolmeen eri osa-alueeseen, jotka ovat energiatehokas lämpötalous lypsykarjatiloilla, energiatehokas sähkötalous lypsykarjatiloilla sekä laskentamallien laatiminen ja kehittäminen. Hankkeen ensimmäisessä vaiheessa tehdään kartoitus olemassa olevista energiatehokkuuteen liittyvistä laitteista sekä uusiutuvan energiantuotannon vaihtoehdoista lypsykarjatiloilla. Toisessa vaiheessa totetutetaan käytännön mittauksia tiloilla ja kolmannessa vaiheessa laaditaan uusia laskentamalleja ja kehitetään olemassa olevia hankkeessa kootun ja tuotetun tiedon perusteella.

\section{Energiatehokas lämpötalous lypsykarjatiloilla}

Eläimet itsessään kestävät melko hyvin kylmiä lämpötiloja ja tuottavat huomattavalla tavalla myös lämpöä. Lämmön tarvetta on lypsykarjatiloilla kuitenkin lypsytiloissa, maitohuoneessa, sosiaalitiloissa sekä poikima-, sairas- ja vasikkaosastoilla. Kylmimmillä pakkasilla lisälämpöä tarvitaan usein myös koko tuotantorakennuksessa, mutta samalla ilmanlaadusta ei kuitenkaan tulisi tinkiä. Erityisesti tuotantorakennuksen eläintilojen suhteellinen kosteuteen tulisi kiinnittää huomiota, koska kosteus on suuri ongelma erityisesti talvella ja vaikuttaa erityisesti vasikoiden hengitystiesairauksiin ja lehmien utareterveystilanteeseen.

Lypsykarjatilojen energiatehokkaan lämpötalouden osalta ERKKA-hankkeessa keskitytään lämmönsiirtimien ja lämpöpumpputekniikan hyödyntämiseen lämmityksessä ja jäähdytyksessä, ilmastoinnin energiakulutuksen määrittämiseen ja ilmanlaadun tarkkailuun lämmityskauden aikana sekä lämmityskauden aikaisten lämpöhäviöiden määrittämiseen ja lämpövuotojen paikallistamiseen lämpökameralla. Koska lypsykarjatiloilla tarvitaan sekä lämmitystä että jäähdytystä, voidaan tuotantoyksikön energiatehokkuutta parantaa lämmönsiirtimien tai lämpöpumppujen avulla. Lisäksi erilaiset lämpöpumpputekniikat voisivat olla hyödyllisiä ja energiatehokkaita $\mathrm{mm}$. maidon jäähdytyksessä. Tällöin voidaan vähentää lämmitystarvetta energiatehokkuuden lisäämisellä. 
Lämpötalouteen liittyen hankkeeseen valittaville esimerkkitiloille laaditaan energiasuunnitelma, jossa lasketaan rakennus- ja tuotekohtaisia energiankulutuksen tunnuslukuja. Samalla arvioidaan myös tuotantorakennusten ja lämpöjärjestelmien lämpöhäviöitä. Seuraavassa vaiheessa 2-4 esimerkkitilalla toteutetaan mittauksia todellisten lämpöhäviöiden määrittämiseksi. Lämmöntuotantoyksikön ja rakennusten lisäksi huomion kohteena ovat lämmönjakeluverkoston lämpöhäviöt. Tavoitteena on selvittää, millaisia lämpövuotoja erilaisista rakenteista, rakennusratkaisuista, rakennusmateriaaleista ja lämmönjakeluverkostoista syntyy käytännössä sekä miten tulokset vastaavat teoreettisten laskelmien tuloksia. Tutkittavia rakennuksia seurataan Savonia-ammattikorkeakoulun rakennustekniikan yksikön lämpökameralla. Lisäksi monitoroidaan rakennusten ulko- ja sisälämpötilaa sekä ilmanlaatua kuvaavia parametrejä kuten $\mathrm{CO}_{2}$-pitoisuutta, suhteellista kosteutta ja ammoniakkia hankkeen seurantajakson ajan.

\section{Energiatehokas sähkötalous lypsykarjatiloilla}

Lypsykarjatiloilla merkittävä osa energiankulutuksesta on sähkönkulutusta ja se muodostuu pääasiassa lypsyn, lämmityksen, ruokinnan, ilmanvaihdon, valaistuksen ja lannanpoiston sähkönkulutuksesta. Useissa tutkimuksissa on todettu, että lypsykarjatilojen sähkönkulutuksissa on huomattavia vaihteluja tilojen välillä. Kulutuksen vaihteluja voivat selittää erilaiset tuotantomenetelmät sekä mahdollisesti myös se, että investoinneissa ja työtavoissa ei ole kiinnitetty huomiota energiankulutukseen. Yksi selittävä tekijä sähkönkulutuksen eroissa tilojen välillä on sähkömoottoreiden määrät ja niiden käyttöasteet.

Sähkönkulutuksen aiheuttamia kuluja ja päästöjä voidaan vähentää lisäämällä tuotannon energiatehokkuutta. Toisaalta tutkimuksen kohteena ovat myös tilojen omavaraisen sähköntuotannon mahdollisuudet. Sähköä voidaan tuottaa pienessä mittakaavassa mm. biokaasulaitoksilla, tuuli-, aurinko- ja vesivoimalla sekä termisellä kaasutuksella.

ERKKA-hankkeessa keskitytään lypsykarjatilojen tuotantorakennusten sähkötalouden näkökulmasta laitteiden energiankulutuksen mittauksiin, tilan omavaraisen sähköntuotannon tarkasteluun termisellä kaasutuksella (pienen teholuokan CHP-laitos) ja osittain tilan omavaraisen sähköntuotannon tarkasteluun myös muilla uusiutuvilla energianmuodoilla.

Terminen kaasutus on mielenkiinnonkohteena, koska sitä voidaan käyttää sähköntuotannossa pienessäkin mittakaavassa. Teknologia on käytössä vielä hyvin rajatusti ja se vaatii lisää tutkimusta ja laskelmia menetelmän taludellisesta kannattavuudesta. Maatiloilla on yleensä puubiomassaa hallussaan ja tätä voisi käyttää kaasutuksessa hyödyksi. Savonia-ammattikorkeakoululla on Varkaudessa energiatekniikan koulutusohjelmassa puukaasuosaamista. Tätä sovelletaan hankkeen myötä myös maatalousympäristöön.

Hankkeessa tutkitaan esimerkkitilojen avulla millaisia eroja energiankulutuksessa on erilaisilla ratkaisuilla. Kiinnostuksen kohteena ovat varsinkin lypsyteknologian ja ruokintaketjun sähkölaitteet sekä ilmanvaihdon ja valaistuksen toimivuus ja sen vaikutus energiataseeseen. Eri laitteiden kulutuksia otetaan vertailuun käytännön kohteissa. Myös työskentelytavat energiankulutuksen osatekijänä huomioidaan. Saatavia tuloksia vertaillaan laskennallisten energiasuunnitelmien tuloksiin.

\section{Laskentamallien laatiminen ja kehittäminen}

Savonia-ammattikorkeakoululta on valmistunut maaliskuussa 2010 opinnäytetyö aiheena lypsykarjatilan tuotantorakennuksen energiankulutuslaskuri (Meriläinen\&Putkonen, 2010). Työssä laadittiin Excel-pohjainen energiankulutuslaskuri, jonka tavoitteena on palvella ensisijaisesti uutta lypsykarjatilan automaattilypsyllä varustettua tuotantorakennusta. Tärkeimpinä kohteina laskuri laskee ilmastoinnin, lannanpoiston, ruokinnan, valaistuksen, lämmityksen, maidonjäähdytyksen, veden lämmityksen ja lypsyn vaikutukset sähkön kulutukseen tuotantorakennuksessa. Lähtötietoina laskuriin syötetään moottoreiden määrät, moottoritehot sekä niiden käyttöajat ja -asteet. Tuloksena laskurista saadaan kulutuslukemat sekä kustannukset, huomioiden sähkön hinnan.

Edellä kuvatun Savonian oman laskurin, muiden hankkeen käyttöön saatavien laskurien sekä hankkeen aikana kootun tiedon pohjalta muodostetaan kokonaisuus, jossa kootaan yhteen maitotilojen tuotantorakennusten energiataseita koskevaa tutkimustietoa. Olemassa olevia laskentamenetelmiä tarkastellaan ja niiden tarkkuuksia kehitetään hankkeen myötä. Erityinen painotus on taloudellisuuden määrittämisellä. Hankkeessa pyritään myös ennakoimaan tulevia trendejä liittyen sekä energianhintoihin, laitetekniikoihin että lypsykarjatilojen kannattavuusnäkymiin. Hankkeessa tarkastellaan toimintamalleja edellä mainittujen osa-alueiden näkökulmasta. 


\section{Odotettavissa olevat tulokset}

Hankkeen tuloksena saadaan tietoa siitä, kuinka lypsykarjatilat voivat vähentää uusiutumattoman energian kulutusta rakennusteknisillä keinoilla, laiteteknisillä valinnoilla ja uusiutuvien energianlähteiden käytöllä ja milloin tilat voivat parantaa kannattavuuttaan näillä keinoilla. Tulokset on tarkoitettu hyödynnettäväksi investoivilla tiloilla, neuvonnassa sekä rakennussuunnittelussa. Hankkeessa kootusta ja tuotetusta tiedosta laaditaan yhtenäinen ja selkeä tieto- ja opetuspaketti, joka on saatavilla hankkeen loppupuolella Savonia-ammattikorkeakoulun verkkosivuilla.

Lämpötalouden osalta tuloksena tutkimuksesta saadaan selville, missä ja millaisista ratkaisuista erilaisten tuotantorakennusten suurimmat lämpöhäviöt syntyvät. Kokeissa saadun tiedon pohjalta pyritään määrittämään suosituksia parhaista vaihtoehdoista käytettäväksi suunnittelussa sekä jo olemassa olevien rakennusten korjauksissa.

Sähkötalouden osalta tuloksena saadaan tietoa laitteiden todellisesta energiankulutuksesta sekä vertailutietoa eri laitetyyppien kulutuksista. Lisäksi saadaan tietoa siitä, millaisilla laitevalinnoilla, tehonsäädöillä ja työskentelytavoilla voidaan energiankulutusta vähentää. Näitä tietoja käytetään pohjana laskentamalleissa.

Hankkeen tulosten perusteella kehitetään ja parannetaan olemassa olevien soveltuvien laskentamallien toimivuutta ja laskentatarkkuuksia arvioitaessa tilakohtaisesti uusiutuvien energiamuotojen hyödyntämismahdollisuuksia ja -kannattavuuksia. Tulosten pohjalta on mahdollista päivittää ja kalibroida jo olemassa olevia laskureita. Hanke myös jalkauttaa energiaan liittyviä laskentamalleja rakennussuunnittelijoiden ja neuvojien käyttöön.

\section{Kirjallisuus}

Työtehoseura, 2005. Työtehoseuran maataloustiedote 12/2005 (585)

Suomen Gallup Elintarviketieto Oy, 2008

Energiapalveludirektiivi, Direktiivi energian tehokkaasta loppukäytöstä ja energiapalveluista, 2006/32/EY.

RES-direktiivi, Direktiivi uusiutuvista energianlähteistä peräisin olevan energian käytön edistämisestä, 2008/29/EY.

Meriläinen Markus, Putkonen Pasi, 2010. Lypsykarjatilan tuotantorakennuksen energiankulutuslaskuri sähkölle. Opinnäytetyö, Savonia-ammattikorkeakoulu. 